\title{
Peroxynitrite detoxification by ferryl Mycobacterium leprae truncated hemoglobin 0
}

\author{
Paolo Ascenzi ${ }^{\mathrm{a}, \mathrm{b}, *}$, Elisabetta De Marinis ${ }^{\mathrm{a}}$, Paolo Visca ${ }^{\mathrm{a}, \mathrm{b}}$, Chiara Ciaccio ${ }^{\mathrm{c}, \mathrm{d}}$, Massimo Coletta ${ }^{\mathrm{c}, \mathrm{d}}$ \\ a Department of Biology and Interdepartmental Laboratory for Electron Microscopy, University Roma Tre, Viale Guglielmo Marconi 446, I-00146 Roma, Italy \\ ${ }^{\mathrm{b}}$ National Institute for Infectious Diseases I.R.C.C.S. 'Lazzaro Spallanzani', Via Portuense 292, I-00149 Roma, Italy \\ ${ }^{\mathrm{C}}$ Department of Experimental Medicine and Biochemical Sciences, University of Roma 'Tor Vergata', Via Montpellier 1, I-00133 Roma, Italy \\ ${ }^{\mathrm{d}}$ Interuniversity Consortium for the Research on the Chemistry of Metals in Biological Systems (CIRCMSB), Piazza Umberto I 1, I-70100 Bari, Italy
}

\section{A R T I C L E I N F O}

\section{Article history:}

Received 15 January 2009

Available online 23 January 2009

\section{Keywords:}

Mycobacterium leprae

Truncated hemoglobin $\mathrm{O}$

Peroxynitrite

Hydrogen peroxide

Carbon dioxide

Detoxification of reactive nitrogen and oxygen species

\begin{abstract}
A B S T R A C T
During infection, Mycobacterium leprae is faced with the host macrophagic environment limiting the growth of the bacilli. However, (pseudo-)enzymatic detoxification systems, including truncated hemoglobin $\mathrm{O}(\mathrm{Ml}$-trHbO), could allow this mycobacterium to persist in vivo. Here, kinetics of peroxynitrite $\left(\mathrm{ONOOH} / \mathrm{ONOO}^{-}\right)$detoxification by ferryl $\mathrm{Ml}$-trHbO $(\mathrm{Ml}$-trHbO-Fe$(\mathrm{IV})=\mathrm{O})$, obtained by treatment with $\mathrm{H}_{2} \mathrm{O}_{2}$, is reported. Values of the second-order rate constant for peroxynitrite detoxification by $\mathrm{Ml}-$ trHbO-Fe(IV) $=\mathrm{O}$ (i.e., of $\mathrm{Ml}$-trHbO-Fe(III) formation; $k_{\mathrm{on}}$ ), at $\mathrm{pH} 7.2$ and $22.0^{\circ} \mathrm{C}$, are $1.5 \times 10^{4} \mathrm{M}^{-1} \mathrm{~s}^{-1}$, and $2.2 \times 10^{4} \mathrm{M}^{-1} \mathrm{~s}^{-1}$, in the absence of and presence of physiological levels of $\mathrm{CO}_{2}\left(\sim 1.2 \times 10^{-3} \mathrm{M}\right)$, respectively. Values of $k_{\mathrm{on}}$ increase on decreasing $\mathrm{pH}$ with a $\mathrm{p} K_{\mathrm{a}}$ value of 6.7 , this suggests that $\mathrm{ONOOH}$ reacts preferentially with $M l$-trHbO-Fe(IV) $=0$. In turn, peroxynitrite acts as an antioxidant of $M l$ trHbO- $\mathrm{Fe}(\mathrm{IV})=0$, which could be responsible for the oxidative damage of the mycobacterium. As a whole, $\mathrm{Ml}$-trHbO can undertake within the same cycle $\mathrm{H}_{2} \mathrm{O}_{2}$ and peroxynitrite detoxification.
\end{abstract}

(c) 2009 Elsevier Inc. All rights reserved.
During infection, Mycobacterium leprae is faced with the host macrophagic environment, where low $\mathrm{pH}$, low $\mathrm{pO}_{2}$, and high carbon dioxide $\left(\mathrm{CO}_{2}\right)$ levels, combined with reactive nitrogen and oxygen species including peroxynitrite $\left(\mathrm{ONOO}^{-} / \mathrm{ONOOH}\right)^{1}$ and hydrogen peroxide $\left(\mathrm{H}_{2} \mathrm{O}_{2}\right)$, contribute to limit the growth of the bacilli and to host tissue damage [1-10]. Peroxynitrite is more reactive than its precursors nitrogen monoxide ( $\mathrm{NO})$ and superoxide $\left(\mathrm{O}_{2}{ }^{-}\right)$, promoting oxidative tissue injury by different mechanisms. In fact, peroxynitrite reacts with bio-molecules either directly or after homolysis to nitrite radical ( $\left.{ }^{\circ} \mathrm{NO}_{2}\right)$ and hydroxyl radical (' $\left.\mathrm{OH}\right)$. Furthermore, one of the main targets of peroxynitrite is thought to be $\mathrm{CO}_{2}$, present in millimolar concentrations in most fluids and tissues, apparently forming an adduct whose composition is believed to be $\mathrm{ONOOC}(\mathrm{O}) \mathrm{O}^{-}$(named 1-carboxylato-2-nitrosodioxidane or nitroso-

Abbreviations: heme-Fe(III), ferric heme-protein; heme-Fe(IV) $=0$, ferryl [oxo$\mathrm{Fe}(\mathrm{IV})]$ hemeprotein; heme-Fe(II), ferrous deoxygenated heme-protein; heme$\mathrm{Fe}(\mathrm{II})-\mathrm{NO}$, ferrous nitrosylated heme-protein; heme-Fe(II)- $\mathrm{O}_{2}$, ferrous oxygenated heme-protein; $\mathrm{Hb}$, hemoglobin; Lb, leghemoglobin; $\mathrm{Mb}$, myoglobin; trHbO, truncated hemoglobin $\mathrm{O} ; \mathrm{Ml}$-trHbO, Mycobacterium leprae trHbO.

* Corresponding author. Address: Department of Biology and Interdepartmental Laboratory for Electron Microscopy, University Roma Tre, Viale Guglielmo Marconi 446, I-00146 Roma, Italy. Fax: +39 0657336321.

E-mail address: ascenzi@uniroma3.it (P. Ascenzi).

1 The recommended IUPAC nomenclature for peroxynitrite is oxoperoxonitrate $\left(1^{-}\right)$ and for peroxynitrous acid is hydrogen oxoperoxonitrate. The term peroxynitrite is used in the text to refer generically to both $\mathrm{ONOO}^{-}$and its conjugate acid $\mathrm{ONOOH}$ (see [14]). peroxocarbonate), which is a stronger nitrating agent than $\mathrm{ONOOH}$ and is homolyzed to trioxocarbonate $\left(\cdot 1^{-}\right)\left(\mathrm{CO}_{3}{ }^{-}\right)$and $\cdot \mathrm{NO}_{2}[11-16]$. Note that leukocyte peroxidase catalyzes peroxynitrite conversion to hydrogen-peroxide-halide, representing an efficient antimicrobial agent. Thus, the respiratory burst of phagocytes serves as the primary source of $\mathrm{H}_{2} \mathrm{O}_{2}$ for peroxidase-catalyzed reactions. In addition, microorganisms can generate $\mathrm{H}_{2} \mathrm{O}_{2}$, thus contributing to limit their growth by the peroxidase system [1,17-19].

The ability of $M$. leprae to persist in vivo in the presence of reactive nitrogen and oxygen species implies the presence in this elusive mycobacterium of (pseudo-)enzymatic detoxification systems, including truncated hemoglobin $\mathrm{O}(\mathrm{Ml}$-trHbO) [7,9,20-25]. Ferrous oxygenated and nitrosylated $M l$-trHbO $\left(M l-t r H b O-F e(I I)-\mathrm{O}_{2}\right.$ and $\mathrm{Ml}$-trHbO-Fe(II)-NO, respectively) has been reported to facilitate 'NO, $\mathrm{O}_{2}$, and peroxynitrite detoxification, moreover ferryl $\mathrm{Ml}$-trHbO $(\mathrm{Ml}$-trHbO-Fe $(\mathrm{IV})=\mathrm{O})$ acts as a $\cdot \mathrm{NO}$, nitrite $\left(\mathrm{NO}_{2}{ }^{-}\right)$, and $\mathrm{H}_{2} \mathrm{O}_{2}$ scavenger $[9,20,21,23-25]$. Peroxynitrite scavenging by ferrous oxygenated and nitrosylated heme-proteins (heme-Fe(II)- $\mathrm{O}_{2}$ and heme$\mathrm{Fe}(\mathrm{II})-\mathrm{NO}$, respectively), leading to the ferric heme-protein derivative (heme-Fe(III)), needs a specific reductase(s) to restore the ferrous species (heme-Fe(II)) in order to start a new catalytic cycle (see [26]). Since a reductase system(s) has been identified only for hemoglobin $(\mathrm{Hb})$, flavohemoglobin, and myoglobin $(\mathrm{Mb})$ (see [2729]), alternative reaction mechanism(s) that does not need a partner reductase(s) could be operative in vivo. Recently, ' $\mathrm{NO}$ and $\mathrm{NO}_{2}{ }^{-}$ have been reported to be detoxified by the ferryl derivative of 
heme-proteins (heme-Fe(IV) $=0$ ) leading to heme-Fe(III) and $\mathrm{NO}_{2}{ }^{-}$ and $\mathrm{NO}_{2}$, respectively, then heme-Fe(III) can be oxidized to heme$\mathrm{Fe}(\mathrm{IV})=\mathrm{O}$ by $\mathrm{H}_{2} \mathrm{O}_{2}$. Therefore, $\cdot \mathrm{NO}, \mathrm{NO}_{2}{ }^{-}$, and $\mathrm{H}_{2} \mathrm{O}_{2}$ facilitate the heme-Fe(IV) $=\mathrm{O} /$ heme-Fe(III) cycle (see $[25,26,30-32]$ ).

Here, kinetics of peroxynitrite detoxification by $\mathrm{Ml}$-trHbO$\mathrm{Fe}(\mathrm{IV})=\mathrm{O}$, obtained by treatment with $\mathrm{H}_{2} \mathrm{O}_{2}$, are reported. In turn, peroxynitrite acts as an antioxidant of $\mathrm{Ml}$-trHbO-Fe(IV) $=0$ leading to $\mathrm{Ml}$-trHbO-Fe(III). Therefore, $\mathrm{Ml}$-trHbO can undertake within the same cycle not only ${ }^{\cdot} \mathrm{NO}, \mathrm{NO}_{2}{ }^{-}$, and $\mathrm{H}_{2} \mathrm{O}_{2}$ scavenging [25], but also peroxynitrite detoxification (present study).

\section{Materials and methods}

Ml-trHbO-Fe(III) was prepared as previously reported [33]. The $\mathrm{Ml}$-trHbO-Fe(III) concentration was determined by measuring the optical absorbance at $409 \mathrm{~nm}\left(\varepsilon_{409 \mathrm{~nm}}=1.15 \times 10^{5} \mathrm{M}^{-1} \mathrm{~cm}^{-1}\right)$ [20]. The $M l$-trHbO-Fe(IV) $=0$ stock solution was prepared by adding 10-25 equivalents of $\mathrm{H}_{2} \mathrm{O}_{2}$ to a buffered $\mathrm{Ml}$-trHbO-Fe(III) solution $\left(3.0 \times 10^{-2} \mathrm{M}\right.$ phosphate buffer, $\left.\mathrm{pH} 7.2\right)$, at $20.0^{\circ} \mathrm{C}$. After a reaction time of $10-20 \mathrm{~min}$, the $\mathrm{Ml}$-trHbO-Fe(IV) $=0$ solution was stored on ice and used within $1 \mathrm{~h}$ [25]. Before each experiment, the $\mathrm{Ml}$-trHbO-Fe(IV) $=\mathrm{O}$ stock solution was diluted to the desired $\mathrm{pH}$ value (ranging between 6.2 and 8.1) with the appropriate $4.0 \times 10^{-1} \mathrm{M}$ phosphate buffer solution. The $\mathrm{Ml}$-trHbO$-\mathrm{Fe}(\mathrm{IV})=\mathrm{O}$ concentration was determined by measuring the optical absorbance at $419 \mathrm{~nm}\left(\varepsilon_{419 \mathrm{~nm}}=1.06 \times 10^{5} \mathrm{M}^{-1} \mathrm{~cm}^{-1} ; \mathrm{pH} 7.2\right.$ and $\left.20.0^{\circ} \mathrm{C}\right)[25]$.

$\mathrm{H}_{2} \mathrm{O}_{2}$ (from Fluka GmbH, Buchs, Switzerland) was diluted with the $5.0 \times 10^{-2} \mathrm{M}$ phosphate buffer solution ( $\mathrm{pH}$ 7.2). The $\mathrm{H}_{2} \mathrm{O}_{2}$ concentration was determined spectrophotometrically at $240 \mathrm{~nm}$ $\left(\varepsilon_{240 \mathrm{~nm}}=39.4 \mathrm{M}^{-1} \mathrm{~cm}^{-1}\right)$ [34].

Peroxynitrite was prepared from potassium superoxide $\left(\mathrm{KO}_{2}\right)$ and $\mathrm{NO}$ and from nitrous acid $\left(\mathrm{HNO}_{2}\right)$ and $\mathrm{H}_{2} \mathrm{O}_{2}[35,36]$. The peroxynitrite stock solution was diluted with degassed $1.0 \times 10^{-2} \mathrm{M}$ sodium hydroxide $(\mathrm{NaOH})$ to reach the desired concentration $[9,21]$. The peroxynitrite concentration was determined spectrophotometrically at $302 \mathrm{~nm} \quad\left(\varepsilon_{302 \mathrm{~nm}}=1.705 \times 10^{3} \mathrm{M}^{-1} \mathrm{~cm}^{-1}\right)$ $[35,36]$. Decomposed peroxynitrite was obtained by acidification of the peroxynitrite solution [14].

All the other products (from Merck AG, Darmstadt, Germany, or Sigma-Aldrich, St. Louis, MO, USA) were of analytical grade and used without purification.

The solutions of the experiments in the presence of $\mathrm{CO}_{2}$ were prepared by adding the required amount of a $5.0 \times 10^{-1} \mathrm{M} \mathrm{NaHCO}_{3}$ solution $[9,21]$.

Kinetics for peroxynitrite detoxification by $\mathrm{Ml}$-trHbO$-\mathrm{Fe}(\mathrm{IV})=\mathrm{O}$ was determined, in the absence and presence of $\mathrm{CO}_{2}$, by mixing the $\mathrm{Ml}$-trHbO-Fe $(\mathrm{IV})=\mathrm{O}$ (final concentration, $2.7 \times 10^{-6} \mathrm{M}$ ) solution with the peroxynitrite (final concentration, $2.0 \times 10^{-5} \mathrm{M}$ to $4.0 \times 10^{-4} \mathrm{M}$ ) solution, at $\mathrm{pH}$ values ranging between 6.2 and 8.1 (final concentration, $2.0 \times 10^{-1} \mathrm{M}$ phosphate buffer) and $20.0^{\circ} \mathrm{C}$; no gaseous phase was present. Kinetics was monitored between $360 \mathrm{~nm}$ and $460 \mathrm{~nm}$.

The time course of peroxynitrite detoxification by $\mathrm{Ml}$-trHbO-Fe(IV) $=0$, in the absence and presence of $\mathrm{CO}_{2}$, was fitted to a single exponential process according to the minimum reaction mechanism represented by Scheme 1 [37-39].

+ peroxynitrite $+\mathrm{CO}_{2}$

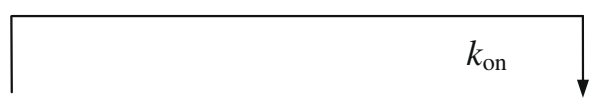

$M l$-trHbO-Fe(IV) $=\mathrm{O}+$ peroxynitrite $\rightarrow M l$-trHbO-Fe(III)

Scheme 1.
Values of the pseudo-first-order rate constant for peroxynitritemediated $\mathrm{Ml}$-trHbO$-\mathrm{Fe}(\mathrm{IV})=\mathrm{O}$ reduction (i.e., $\mathrm{Ml}$-trHbO-Fe(III) formation; $k$ ), in the absence and presence of $\mathrm{CO}_{2}$, were determined according to Eq. (1) [40]:

$[\mathrm{Ml} \text {-trHbO-Fe(IV)}=0]_{t}=[\mathrm{Ml} \text {-trHbO-Fe(IV) }=0]_{i} \times \mathrm{e}^{-k \times t}$

Values of the second-order rate constant for peroxynitrite detoxification by $\mathrm{Ml}$-trHbO-Fe(IV) $=\mathrm{O}$ (i.e., $\mathrm{Ml}$-trHbO-Fe(III) formation; $k_{\text {on }}$ ), in the absence and presence of $\mathrm{CO}_{2}$, were determined according to Eq. (2) [40]:

$k=k_{\text {on }} \times$ [peroxynitrite]

The $\mathrm{p} K_{\mathrm{a}}$ value describing the $\mathrm{pH}$ dependence of $k_{\mathrm{on}}$ for peroxynitrite-mediated detoxification of $\mathrm{Ml}$-trHbO-Fe(IV) $=0$ in the absence of $\mathrm{CO}_{2}$ was obtained, at $20.0^{\circ} \mathrm{C}$, according to Eq. (3) [41-43]:

$k_{\text {on }}=\left(k_{\lim (\mathrm{top})} \times 10^{-\mathrm{pH}}\right) /\left(10^{-\mathrm{pH}}+10^{-\mathrm{p} K_{\mathrm{a}}}\right)+k_{\lim (\text { bottom })}$

where $k_{\lim (t o p)}$ represents the asymptotic value of $k_{\text {on }}$ under conditions where $\mathrm{pH} \ll \mathrm{p} K_{\mathrm{a}}$, and $k_{\lim \text { (bottom) }}$ represents the asymptotic value of $k_{\text {on }}$ under conditions where $\mathrm{pH} \gg \mathrm{p} K_{\mathrm{a}}$.

In some cases, bovine liver catalase was added to the $M l$-trHbO- $\mathrm{Fe}(\mathrm{IV})=\mathrm{O}$ solution prior the reaction with peroxynitrite to destroy excess $\mathrm{H}_{2} \mathrm{O}_{2}$. According to literature [30,31], catalase did not affect peroxynitrite scavenging by $\mathrm{Ml}$-trHbO-Fe(IV) $=0$, in the absence and presence of $\mathrm{CO}_{2}$.

The results are given as mean values of at least four experiments plus or minus the corresponding standard deviation. All data were analyzed using the GraphPad Prism (GraphPad Software Inc., La Jolla, CA, USA) and MatLab (The Math Works Inc., Natick, MA, USA) programs.

\section{Results and discussion}

Mixing $\mathrm{Ml}$-trHbO-Fe(IV) $=0$ and peroxynitrite solutions, in the absence and presence of $\mathrm{CO}_{2}$, causes a shift of the optical absorption maximum of the Soret band (i.e., $\lambda_{\max }$ ) from $419 \mathrm{~nm}$ (i.e., $M l$-trHbO-Fe(IV) $=0$ ) to $409 \mathrm{~nm}$ (i.e., $M l$-trHbO-Fe(III)) and a change of the extinction coefficient from $\varepsilon_{419 \mathrm{~nm}}=1.06 \times$ $10^{5} \mathrm{M}^{-1} \mathrm{~cm}^{-1} \quad$ (i.e., $\quad M l$-trHbO-Fe(IV) $\left.=0\right)$ to $\quad \varepsilon_{409 \mathrm{~nm}}=1.15 \times$ $10^{5} \mathrm{M}^{-1} \mathrm{~cm}^{-1}$ (i.e., $\mathrm{Ml}$-trHbO-Fe(III)), at pH 7.2 and $20.0^{\circ} \mathrm{C}$.

Under all the experimental conditions (i.e., $6.2 \leqslant \mathrm{pH} \leqslant 8.1$, $2.0 \times 10^{-5} \mathrm{M} \leqslant$ [peroxynitrite] $\leqslant 2.0 \times 10^{-4} \mathrm{M}, \quad\left[\mathrm{CO}_{2}\right]=0 \mathrm{M}$ or $1.2 \times 10^{-3} \mathrm{M}$, and $T=20.0^{\circ} \mathrm{C}$ ), the time course for peroxynitrite detoxification by $\mathrm{Ml}$-trHbO- $\mathrm{Fe}(\mathrm{IV})=\mathrm{O}$ corresponds to a monophasic process between $360 \mathrm{~nm}$ and $460 \mathrm{~nm}$ (see Scheme 1 and Fig. 1). Values of the pseudo-first-order rate constant for peroxynitritemediated $\mathrm{Ml}$-trHbO-Fe(IV) $=0$ reduction (i.e., $M l$-trHbO-Fe(III) formation; $k$ ) are wavelength-independent at fixed $\mathrm{pH}$ and peroxynitrite concentration, in the absence and presence of $\mathrm{CO}_{2}$. Plots of $k$ versus peroxynitrite concentration are linear (Fig. 1); at $\mathrm{pH} 7.2$, the slope corresponds to $k_{\text {on }}=1.5 \times 10^{4} \mathrm{M}^{-1} \mathrm{~s}^{-1}$, in the absence of $\mathrm{CO}_{2}$, and $2.2 \times 10^{4} \mathrm{M}^{-1} \mathrm{~s}^{-1}$, in the presence of $\mathrm{CO}_{2}$ (Fig. 1 and Table 1 ). Under all the experimental conditions, the $y$-axis intercept of plots of $k$ versus peroxynitrite concentration is very close to $0 \mathrm{~s}^{-1}$ within the experimental error (Fig. 1), allowing to treat the reaction as virtually irreversible. As expected, decomposed peroxynitrite neither affects the spectroscopic properties nor induces the reduction of $\mathrm{Ml}$-trHbO-Fe(IV) $=0$.

As shown in Fig. 1 and Table 1, values of $k_{\text {on }}$ for peroxynitrite detoxification by $\mathrm{Ml}$-trHbO-Fe(IV) $=0$ increase on decreasing $\mathrm{pH}$ from 8.1 to $6.2\left(2.0 \times 10^{-1} \mathrm{M}\right.$ phosphate buffer $)$, in the absence of $\mathrm{CO}_{2}$. The analysis of data according to Eq. (3) allowed to determine the following parameters: $\mathrm{p} K_{\mathrm{a}}=6.7 \pm 0.1, \quad k_{\lim (\mathrm{top})}=$ $(4.4 \pm 0.1) \times 10^{4} \mathrm{M}^{-1} \mathrm{~s}^{-1}$, and $k_{\text {lim(bottom })}=(6.4 \pm 0.1) \times 10^{3} \mathrm{M}^{-1}$ $\mathrm{s}^{-1}$, at $20.0^{\circ} \mathrm{C}$. The $\mathrm{p} K_{\mathrm{a}}$ value for peroxynitrite detoxification by 

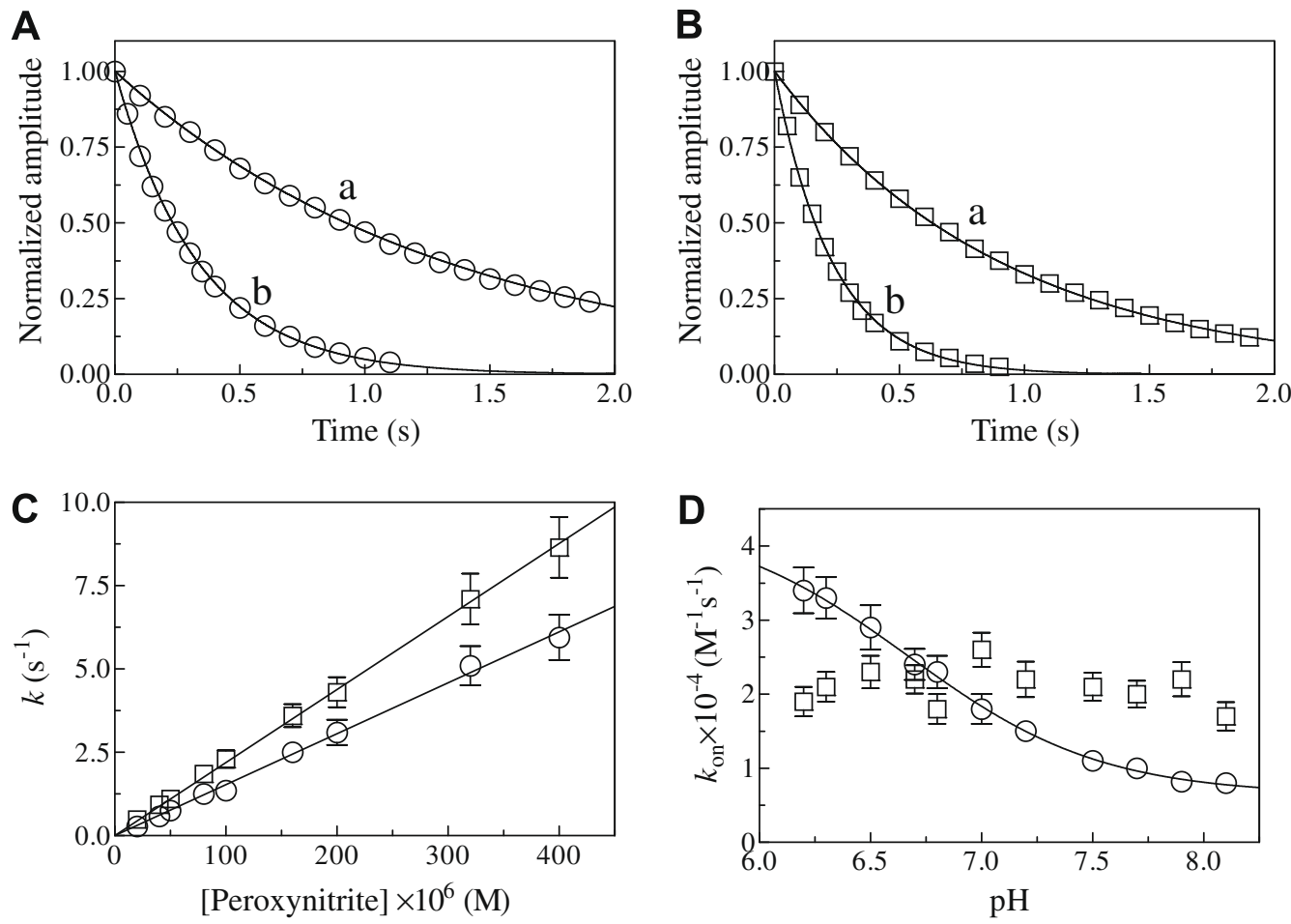

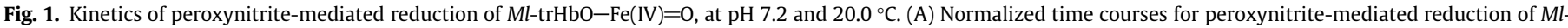

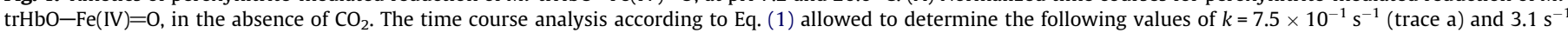

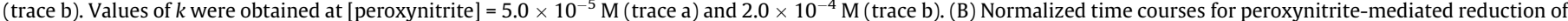

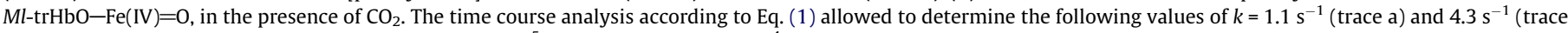

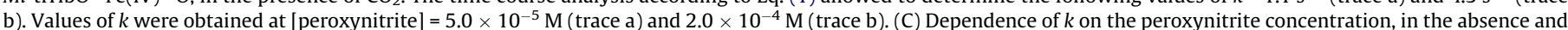

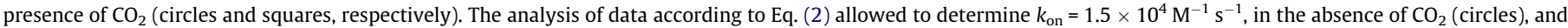

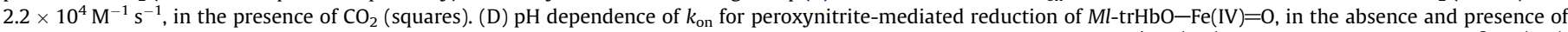

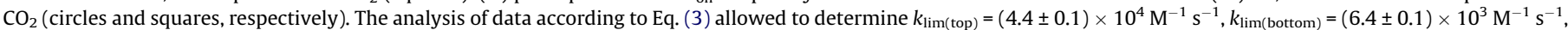

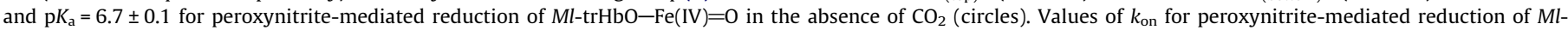

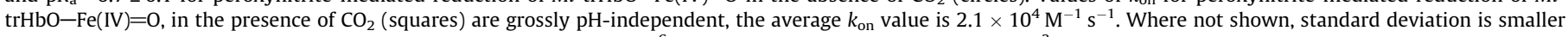
than the symbol. The $\mathrm{Ml}$-trHbO-Fe(IV)=O concentration was $2.7 \times 10^{-6} \mathrm{M}$. The $\mathrm{CO}_{2}$ concentration was $1.2 \times 10^{-3} \mathrm{M}$. For details, see text.

Table 1

Values of $k_{\text {on }}$ for peroxynitrite detoxification by $M l$-trHbO-Fe(IV) $=0$, in the absence and presence of $\mathrm{CO}_{2}$, at $20.0^{\circ} \mathrm{C}{ }^{\text {a }}$

\begin{tabular}{lll}
\hline $\mathrm{pH}$ & $k_{\text {on }}\left(\mathrm{M}^{-1} \mathrm{~s}^{-1}\right)$ & \\
\cline { 2 - 3 } & {$\left[\mathrm{CO}_{2}\right]=0 \mathrm{M}$} & {$\left[\mathrm{CO}_{2}\right]=1.2 \times 10^{-3} \mathrm{M}$} \\
\hline 6.2 & $3.4 \times 10^{4}$ & $1.9 \times 10^{4}$ \\
6.3 & $3.3 \times 10^{4}$ & $2.1 \times 10^{4}$ \\
6.5 & $2.9 \times 10^{4}$ & $2.3 \times 10^{4}$ \\
6.7 & $2.4 \times 10^{4}$ & $2.2 \times 10^{4}$ \\
6.8 & $2.3 \times 10^{4}$ & $1.8 \times 10^{4}$ \\
7.0 & $1.8 \times 10^{4}$ & $2.6 \times 10^{4}$ \\
7.2 & $1.5 \times 10^{4}$ & $2.2 \times 10^{4}$ \\
7.5 & $1.1 \times 10^{4}$ & $2.1 \times 10^{4}$ \\
7.7 & $1.0 \times 10^{4}$ & $2.0 \times 10^{4}$ \\
7.9 & $8.2 \times 10^{3}$ & $2.2 \times 10^{4}$ \\
8.1 & $8.0 \times 10^{3}$ & $1.7 \times 10^{4}$ \\
\hline
\end{tabular}

a $2.0 \times 10^{-1} \mathrm{M}$ phosphate buffer.

$\mathrm{Ml}$-trHbO-Fe(IV) $=\mathrm{O}$ in the absence of $\mathrm{CO}_{2}(=6.7 \pm 0.1)$ corresponds to that reported for the $\mathrm{ONOOH} \leftrightarrow \mathrm{ONOO}^{-}$equilibrium (=6.5-6.8) (see [14]). Therefore, $k_{\lim (\text { top })}$ should represent $k_{\text {on }}$ for $\mathrm{Ml}$-trHbO-Fe(IV) $=\mathrm{O}$ reduction to $\mathrm{Ml}$-trHbO-Fe(III) by $\mathrm{ONOOH}$ at $\mathrm{pH} \ll \mathrm{p} K_{\mathrm{a}}$, while $k_{\lim \text { (bottom) }}$ should be referred to $k_{\text {on }}$ for $\mathrm{Ml}$-trHbO-Fe(IV) $=\mathrm{O}$ reduction to $\mathrm{Ml}$-trHbO-Fe(III) by $\mathrm{ONOO}^{-}$at $\mathrm{pH} \gg \mathrm{p} K_{\mathrm{a}}$. In this respect, the reaction mechanisms proposed for heme- $\mathrm{Fe}(\mathrm{IV})=\mathrm{O}$ reduction to heme-Fe(III) by $\mathrm{ONOOH}$ (i.e., at $\left.\mathrm{pH} \ll \mathrm{p} K_{\mathrm{a}}\right)[37-39,44]$ are represented by Schemes 2 and 3 .
On the other hand, the reaction mechanism proposed for heme$\mathrm{Fe}(\mathrm{IV})=\mathrm{O}$ reduction to heme-Fe(III) by $\mathrm{ONOO}^{-}$(i.e., at $\mathrm{pH} \gg \mathrm{pK}_{\mathrm{a}}$ ) $[37-39,44]$ is represented by Scheme 4 .

Remarkably, $k_{\lim (t o p)}$ exceeds $k_{\lim \text { (bottom) }}$ by about one order of magnitude (i.e., $k_{\lim (\text { top })} / k_{\lim (\text { bottom) }}=6.8$ ), similarly to what observed for horse heart $\mathrm{Mb}$ [37]. In addition, values of $k_{\text {on }}$ for $\mathrm{Ml}$ trHbO-Fe(IV) $=0$ reduction to $\mathrm{Ml}$-trHbO-Fe(III) are similar to those reported for Glycine max leghemoglobin (Lb), horse heart $\mathrm{Mb}$, and human $\mathrm{Hb}$ (Table 2) [37-39].

As shown in Fig. 1 and Table 1 , values of $k_{\text {on }}$ for peroxynitrite detoxification by $\mathrm{Ml}$-trHbO-Fe(IV) $=0$ in the presence of $\mathrm{CO}_{2}$ do not show a clear pH dependence (the average $k_{\text {on }}$ value is $\left.2.1 \times 10^{4} \mathrm{M}^{-1} \mathrm{~s}^{-1}\right)$, as also reported for horse heart $\mathrm{Mb}-\mathrm{Fe}(\mathrm{IV})=\mathrm{O}$ and human $\mathrm{Hb}-\mathrm{Fe}(\mathrm{IV})=\mathrm{O}[37,38]$. The lack of $\mathrm{a}$ $\mathrm{pH}$ effect finds the explanation on the basis of the reaction mechanism proposed for heme-Fe(IV) $=0$ reduction to heme$\mathrm{Fe}(\mathrm{III})$ by $\mathrm{ONOOH} / \mathrm{ONOO}^{-}$in the presence of $\mathrm{CO}_{2}[37,38,44]$ and represented by Scheme 5 .

Indeed, the reduction of heme-Fe(IV) $=0$ to heme-Fe(III) occurs upon the reaction with $\mathrm{NO}_{2}$, which represents the rate-limiting step of the whole process. Thus, on the basis of Scheme 5, the formation of $\mathrm{NO}_{2}$ does not depend on the $\mathrm{ONOOH} \leftrightarrow \mathrm{ONOO}^{-}$equilibrium (and thus on $\mathrm{pH}$ ), but instead on the $\mathrm{CO}_{2}$ concentration $[37,38,44]$.

Also in the presence of $\mathrm{CO}_{2}$, values of $k_{\text {on }}$ for $M l$-trHbO-Fe(IV) $=0$ reduction to $\mathrm{Ml}$-trHbO-Fe(III) are similar to those reported for Glycine max Lb, horse heart Mb, and human Hb (Table 2) [37-39]. 


$$
\begin{aligned}
& \text { heme-Fe } \left.(\mathrm{IV})=\mathrm{O}+\mathrm{ONOOH}+\mathrm{H}^{+} \rightarrow \text { heme-Fe(III }\right)+\mathrm{ONOO}^{\bullet}+\mathrm{H}_{2} \mathrm{O} \\
& \mathrm{ONOO}^{\bullet} \rightarrow{ }^{\bullet} \mathrm{NO}+\mathrm{O}_{2} \\
& \text { Scheme } 2 . \\
& \text { ONOOH } \overbrace{{ }^{N} \mathrm{NO}_{2}+{ }^{\circ} \mathrm{OH}}^{\mathrm{NO}_{3}{ }^{-}+\mathrm{H}^{+}} \\
& \text {heme-Fe(IV) }=\mathrm{O}+{ }^{\bullet} \mathrm{NO}_{2} \rightarrow \text { heme-Fe(III)-OONO } \rightarrow \text { heme-Fe(III) }+\mathrm{NO}_{3}{ }^{-} \\
& \text {Scheme } 3 . \\
& \text { heme-Fe(IV) }=\mathrm{O}+\mathrm{ONOO}^{-}+\mathrm{H}^{+} \rightarrow \text { heme-Fe(III) }+\mathrm{ONOO}^{\bullet}+\mathrm{OH}^{-} \\
& \mathrm{ONOO}^{\bullet} \rightarrow{ }^{\bullet} \mathrm{NO}+\mathrm{O}_{2}
\end{aligned}
$$

\begin{tabular}{|c|c|c|c|}
\hline Heme-protein & {$\left[\mathrm{CO}_{2}\right](\mathrm{M})$} & $h_{\mathrm{on}}\left(\mathrm{M}^{-1} \mathrm{~s}^{-1}\right)$ & $k_{\text {on }}\left(\mathrm{M}^{-1} \mathrm{~s}^{-1}\right)$ \\
\hline M. leprae trHbO & $\begin{array}{l}0^{\mathrm{a}} \\
1.2 \times 10^{-3 a} \\
0^{\mathrm{b}} \\
1.2 \times 10^{-3 b}\end{array}$ & $\begin{array}{l}- \\
- \\
4.8 \times 10^{4 b} \\
6.3 \times 10^{5 b}\end{array}$ & $\begin{array}{l}1.5 \times 10^{4 a} \\
2.2 \times 10^{4 a} \\
1.3 \times 10^{4 b} \\
1.7 \times 1^{4 b}\end{array}$ \\
\hline Glycine $\max \mathrm{Lb}^{\mathrm{c}}$ & $\begin{array}{l}0 \\
1.2 \times 10^{-3} \\
0 \\
1.2 \times 10^{-3}\end{array}$ & $\begin{array}{l}- \\
- \\
5.5 \times 10^{4} \\
8.8 \times 10^{5}\end{array}$ & $\begin{array}{l}3.4 \times 10^{4} \\
2.3 \times 10^{5} \\
\mathbf{2 . 1} \times \mathbf{1 0}^{4} \\
\mathbf{3 . 6} \times \mathbf{1 0}^{\mathbf{5}}\end{array}$ \\
\hline Horse heart Mb & $\begin{array}{l}0^{\mathrm{d}} \\
2.5 \times 10^{-3 e} \\
0^{\mathrm{e}} \\
2.5 \times 10^{-3 \mathrm{e}}\end{array}$ & $\begin{array}{l}- \\
- \\
5.4 \times 10^{4 \mathrm{e}} \\
3.1 \times 10^{5 \mathrm{e}}\end{array}$ & $\begin{array}{l}1.9 \times 10^{4 \mathrm{~d}} \\
2.8 \times 10^{4 \mathrm{e}} \\
\mathbf{2 . 2} \times \mathbf{1 0}^{4 \mathrm{e}} \\
\mathbf{3 . 2} \times \mathbf{1 0}^{\mathbf{4 e}}\end{array}$ \\
\hline Human $\mathrm{Hb}^{\mathrm{f}}$ & $\begin{array}{l}0 \\
1.2 \times 10^{-3} \\
0 \\
1.2 \times 10^{-3}\end{array}$ & $\begin{array}{l}- \\
- \\
3.3 \times 10^{4} \\
3.5 \times 10^{5}\end{array}$ & $\begin{array}{l}3.8 \times 10^{4} \\
2.5 \times 10^{5} \\
\mathbf{3 . 3} \times \mathbf{1 0}^{\mathbf{4}} \\
\mathbf{1 . 1} \times \mathbf{1 0}^{\mathbf{5}}\end{array}$ \\
\hline
\end{tabular}

Table 2

Values of kinetic parameters for peroxynitrite detoxification by ferryl and ferrous oxygenated heme-proteins (in italics and bold, respectively; see Schemes 1 and 6 , respectively).

${ }^{\mathrm{a}} \mathrm{pH} 7.2$ and $20.0^{\circ} \mathrm{C}$. Present study.

b $\mathrm{pH} 7.3$ and $20.0^{\circ} \mathrm{C}$. From [21].

c $\mathrm{pH} 7.3$ and $20.0^{\circ} \mathrm{C}$. From [39].

d $\mathrm{pH} 7.5$ and $20.0^{\circ} \mathrm{C}$. From [37].

e pH 7.3 and $20.0^{\circ} \mathrm{C}$. From [37].

f $\mathrm{pH} 7.4$ and $20.0^{\circ} \mathrm{C}$. From [38].
The heme-Fe(III)-OONO transient species (see Schemes 3 and 5 ) has been previously demonstrated to be generated by the reaction of $\mathrm{Ml}$-trHbO- $\mathrm{Fe}(\mathrm{II})-\mathrm{O}_{2}$ with $\cdot \mathrm{NO}$, which is then followed by the decay of $\mathrm{Ml}$-trHbO-Fe(III)-OONO to Ml-trHbO-Fe(III) and $\mathrm{NO}_{3}{ }^{-}[20]$.

It is important to outline that values of $k_{\text {on }}$ for the peroxynitrite detoxification by $\mathrm{Ml}$-trHbO-Fe(IV) $=\mathrm{O}$, in the absence and presence of $\mathrm{CO}_{2}$, determined here (see Scheme 1, Fig. 1, and Table 1) are in agreement with those reported in the literature $[9,21]$ for the second step of peroxynitrite scavenging by $\mathrm{Ml}$-trHbO$-\mathrm{Fe}(\mathrm{II})-\mathrm{O}_{2}$ (i.e., values of $k_{\text {on }}$ given in Scheme 6; see Table 2), as reported for Glycine max $\mathrm{Lb}$, horse heart $\mathrm{Mb}$, and human $\mathrm{Hb}$ (Table 2) [37-39].

This agreement reinforces the idea that we are actually measuring the rate constants for individual steps reported in Schemes 2-5; furthermore, the catalytic parameters for peroxynitrite detoxification by $\mathrm{Ml}$-trHbO- $\mathrm{Fe}(\mathrm{IV})=\mathrm{O}$ in the absence and presence of $\mathrm{CO}_{2}$ are high enough to indicate that this reaction indeed could occur in vivo. However, in contrast to peroxynitrite scavenging by Ml-trHbO-Fe(II)- $\mathrm{O}_{2}$ (Scheme 6) [9,21], peroxynitrite detoxification by $\mathrm{Ml}$-trHbO-Fe(IV)=0 (Scheme 1 ) does not require partner oxido-reductive enzyme(s). Actually, $\mathrm{Ml}$-trHbO-Fe(III) oxidation to $\mathrm{Ml}$-trHbO-Fe(IV) $=\mathrm{O}$ is mediated by $\mathrm{H}_{2} \mathrm{O}_{2}$ [25], and $\mathrm{Ml}$-trHbO-Fe(IV) $=\mathrm{O}$ reduction to $\mathrm{Ml}$-trHbO-Fe(III) is facilitated by peroxynitrite (see Scheme 1, Fig. 1, and Tables 1 and 2), envisaging a short cycle between heme- $\mathrm{Fe}(\mathrm{IV})=0$ and heme- $\mathrm{Fe}(\mathrm{III})$ operated through peroxynitrite without the necessity of a reductase(s). In this framework, it becomes comprehensible why Ml-trHbO-Fe(III) could not require a reductase system(s), which indeed has not yet been identified in this elusive mycobacterium $[9,23]$.

$$
\begin{aligned}
& \mathrm{ONOOH} \stackrel{ \pm \mathrm{H}^{+}}{\leftrightarrow} \mathrm{ONOO}^{-}+\mathrm{CO}_{2} \rightarrow{\mathrm{ONOOC}(\mathrm{O}) \mathrm{O}^{-}}_{{ }_{\mathrm{NO}_{2}+\mathrm{CO}_{3}}{ }^{--}}^{\mathrm{NO}_{3}{ }^{-}+\mathrm{CO}_{2}} \\
& \text { heme-Fe(IV) }=\mathrm{O}+{ }^{\circ} \mathrm{NO}_{2} \rightarrow \text { heme-Fe(III)-OONO } \rightarrow \text { heme-Fe(III) }+\mathrm{NO}_{3}{ }^{-}
\end{aligned}
$$




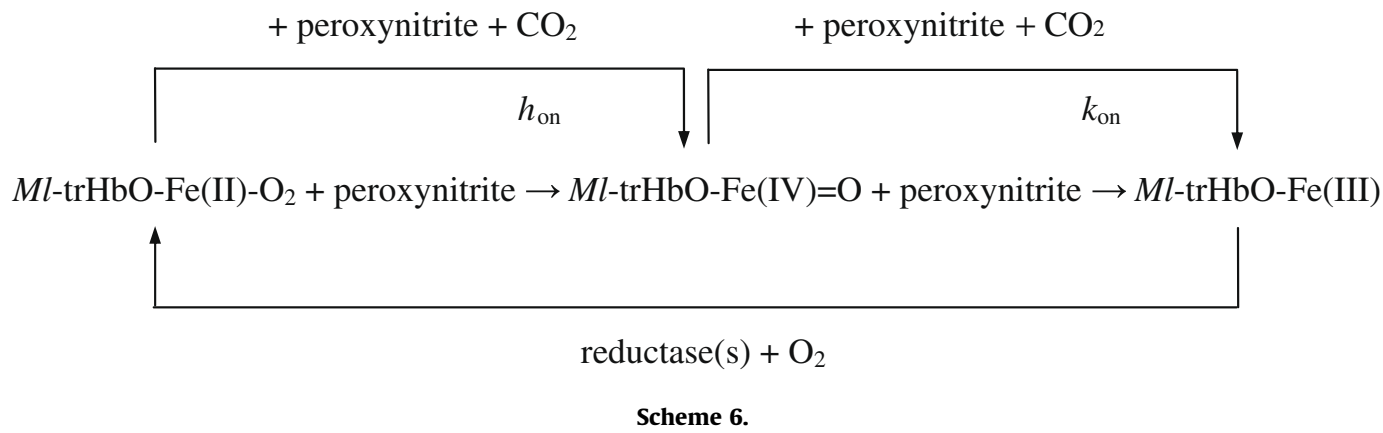

As a whole, $\mathrm{H}_{2} \mathrm{O}_{2}$-induced $\mathrm{Ml}$-trHbO-Fe(IV) $=\mathrm{O}$ could be relevant for $M$. leprae survival in vivo in the presence not only of ' $\mathrm{NO}$ and $\mathrm{NO}_{2}{ }^{-}$ [25] but also of peroxynitrite (present study), in the absence of a suitable reductase system(s) facilitating $M l$-trHbO-Fe(III) and $\mathrm{Ml}$-trHbO-Fe(II) formation. Furthermore, as reported for 'NO and $\mathrm{NO}_{2}{ }^{-}$[25], peroxynitrite acts as an antioxidant (present study) preventing the $\mathrm{Ml}$-trHbO-Fe(IV)=O-mediated oxidation of mycobacterial (macro)molecules such as membrane lipids (i.e., lipid peroxidation).

\section{Acknowledgments}

This work was partially supported by grants from the Ministry for Education, University, and Research of Italy (Department of Biology, University Roma Tre, Roma, Italy, 'CLAR 2008' to P.A.) and from the Ministry of Health of Italy (National Institute for Infectious Diseases I.R.C.C.S. 'Lazzaro Spallanzani', Roma, Italy, 'Ricerca corrente 2008' to P.A.).

\section{References}

[1] S.J. Klebanoff, C.C. Shepard, Toxic effect of the peroxidase-hydrogen peroxidehalide antimicrobial system on Mycobacterium leprae, Infect. Immun. 44 (1984) 534-536.

[2] W.R. Winrow, P.G. Winyard, C.J. Morris, D.R. Blake, Free radicals in inflammation: second messengers and mediators of tissue destruction, $\mathrm{Br}$. Med. Bull. 49 (1993) 506-522.

[3] J. MacMicking, Q.W. Xie, C. Nathan, Nitric oxide and macrophage function, Annu. Rev. Immunol. 15 (1997) 323-350.

[4] C. Ratledge, J. Dale (Eds.), Mycobacteria Molecular Biology and Virulence, Blackwell Science, Oxford, 1999.

[5] C. Nathan, M.U. Shiloh, Reactive oxygen and nitrogen intermediates in the relationship between mammalian hosts and microbial pathogens, Proc. Natl. Acad. Sci. USA 97 (2000) 8841-8848.

[6] A.M. Cooper, L.B. Adams, D.K. Dalton, R. Appelberg, S. Ehlers, IFN-c and NO in mycobacterial disease: new jobs for old hands, Trends Microbiol. 10 (2002) 221-226.

[7] P. Visca, G. Fabozzi, M. Milani, M. Bolognesi, P. Ascenzi, Nitric oxide and Mycobacterium leprae pathogenicity, IUBMB Life 54 (2002) 95-99.

[8] D.M. Scollard, L.B. Adams, T.P. Gillis, J.L. Krahenbuhl, R.W. Truman, D.L. Williams, The continuing challenges of leprosy, Clin. Microbiol. Rev. 19 (2006) 338-381.

[9] P. Ascenzi, P. Visca, Scavenging of reactive nitrogen species by mycobacterial truncated hemoglobins, Methods Enzymol. 436 (2008) 317-337.

[10] D.M. Scollard, The biology of nerve injury in leprosy, Lepr. Rev. 79(2008)242-253.

[11] S.V. Lymar, J.K. Hurst, Rapid reaction between peroxynitrite ion and carbon dioxide: implications for biological activity, J. Am. Chem. Soc. 117 (1995) 8867-8868.

[12] J.S. Beckman, W.H. Koppenol, Nitric oxide, superoxide, and peroxynitrite: the good, the bad, and the ugly, Am. J. Physiol. 271 (1996) C1424-C1437.

[13] P. Ascenzi, A. Bocedi, P. Visca, M. Minetti, E. Clementi, Does $\mathrm{CO}_{2}$ modulate peroxynitrite specificity?, IUBMB Life 58 (2006) 611-613

[14] S. Goldstein, J. Lind, G. Merényi, Chemistry of peroxynitrites and peroxynitrates, Chem. Rev. 105 (2005) 2457-2470.

[15] S. Herold, A. Fago, Reactions of peroxynitrite with globin proteins and their possible physiological role, Comp. Biochem. Physiol. A Mol. Integr. Physiol. 142 (2005) 124-129.

[16] S. Goldstein, G. Merényi, The chemistry of peroxynitrite: implications for biological activity, Methods Enzymol. 436 (2008) 49-61.

[17] P.C. Andrews, N.I. Krinsky, A kinetic analysis of the interaction of human myeloperoxidase with hydrogen peroxide, chloride ions, and protons, J. Biol. Chem. 257 (1982) 13240-13245.

[18] H.B. Dunford, Heme Peroxidases, Wiley-VCH, New York, 1999.
[19] S.J. Klebanoff, Myeloperoxidase: friend and foe, J. Leukoc. Biol. 77 (2005) 598-625

[20] P. Ascenzi, A. Bocedi, M. Bolognesi, G. Fabozzi, M. Milani, P. Visca, Nitric oxide scavenging by Mycobacterium leprae GlbO involves the formation of the ferric heme-bound peroxynitrite intermediate, Biochem. Biophys. Res. Commun. 339 (2006) 450-456.

[21] P. Ascenzi, M. Milani, P. Visca, Peroxynitrite scavenging by ferrous truncated hemoglobin GlbO from Mycobacterium leprae, Biochem. Biophys. Res. Commun. 351 (2006) 528-533.

[22] G. Fabozzi, P. Ascenzi, S. Di Renzi, P. Visca, Truncated hemoglobin GlbO from Mycobacterium leprae alleviates nitric oxide toxicity, Microb. Pathog. 40 (2006) 211-220.

[23] P. Ascenzi, M. Bolognesi, M. Milani, M. Guertin, P. Visca, Mycobacterial truncated hemoglobins: from genes to functions, Gene 398 (2007) 42-51.

[24] P. Ascenzi, M. Bolognesi, P. Visca, NO dissociation represents the rate limiting step for $\mathrm{O}_{2}$-mediated oxidation of ferrous nitrosylated Mycobacterium leprae truncated hemoglobin O, Biochem. Biophys. Res. Commun. 357 (2007) 809-814.

[25] P. Ascenzi, E. De Marinis, M. Coletta, P. Visca, $\mathrm{H}_{2} \mathrm{O}_{2}$ and $\mathrm{NO}$ scavenging by Mycobacterium leprae truncated hemoglobin $\mathrm{O}$, Biochem. Biophys. Res. Commun. 373 (2008) 197-201.

[26] E. De Marinis, L. Casella, C. Ciaccio, M. Coletta, P. Visca, P. Ascenzi, Catalytic peroxidation of nitrogen monoxide and peroxynitrite by globins, IUBMB Life 61 (2009) 62-73.

[27] A.J. Gow, B.P. Luchsinger, J.R. Pawloski, D.J. Singel, J.S. Stamler, The oxyhemoglobin reaction of nitric oxide, Proc. Natl. Acad. Sci. USA 96 (1999) 9027-9032

[28] M. Brunori, Nitric oxide moves myoglobin centre stage, Trends Biochem. Sci. 26 (2001) 209-210.

[29] A. Bonamore, A. Boffi, Flavohemoglobin: structure and reactivity, IUBMB Life 60 (2008) 19-28.

[30] S. Herold, F.J. Rehmann, Kinetic and mechanistic studies of the reactions of nitrogen monoxide and nitrite with ferryl myoglobin, J. Biol. Inorg. Chem. 6 (2001) 543-555

[31] S. Herold, F.J. Rehmann, Kinetics of the reactions of nitrogen monoxide and nitrite with ferryl hemoglobin, Free Radic. Biol. Med. 34 (2003) 531-545.

[32] S. Herold, A. Puppo, Kinetics and mechanistic studies of the reactions of metleghemoglobin, ferrylleghemoglobin, and nitrosylleghemoglobin with reactive nitrogen species, J. Biol. Inorg. Chem. 10 (2005) 946-957.

[33] P. Visca, G. Fabozzi, A. Petrucca, C. Ciaccio, M. Coletta, G. De Sanctis, M. Milani, M. Bolognesi, P. Ascenzi, The truncated hemoglobin from Mycobacterium leprae, Biochem. Biophys. Res. Commun. 294 (2002) 1064-1070.

[34] H. Østdal, B. Daneshvar, L.H. Skibsted, Reduction of ferrylmyoglobin by $\beta-$ lactoglobulin, Free Radic. Res. 24 (1996) 429-438.

[35] D.S. Bohle, P.A. Glassbrenner, B. Hansert, Syntheses of pure tetramethylammonium peroxynitrite, Methods Enzymol. 269 (1996) 302-311.

[36] W.H. Koppenol, R. Kissner, J.S. Beckman, Syntheses of peroxynitrite: to go with the flow or on solid grounds?, Methods Enzymol 269 (1996) 296-302.

[37] S. Herold, M. Exner, F. Boccini, The mechanism of the peroxynitrite-mediated oxidation of myoglobin in the absence and presence of carbon dioxide, Chem. Res. Toxicol. 16 (2003) 390-402.

[38] F. Boccini, S. Herold, Mechanistic studies of the oxidation of oxyhemoglobin by peroxynitrite, Biochemistry 43 (2004) 16393-16404.

[39] S. Herold, A. Puppo, Oxyleghemoglobin scavenges nitrogen monoxide and peroxynitrite: a possible role in functioning nodules?, J Biol. Inorg. Chem. 10 (2005) 935-945.

[40] E. Antonini, M. Brunori, Hemoglobin and Myoglobin in their Reactions with Ligands, North-Holland Publishing Co., Amsterdam, 1971.

[41] S. Pfeiffer, A.C. Gorren, K. Schmidt, E.R. Werner, B. Hansert, D.S. Bohle, B. Mayer, Metabolic fate of peroxynitrite in aqueous solutions. Reaction with nitric oxyde and $\mathrm{pH}$-dependent decomposition to nitrite and oxygen in a 2:1 stoichiometry, J. Biol. Chem. 272 (1997) 3465-3470.

[42] S. Herold, K. Shivashankar, Metmyoglobin and methemoglobin catalyze the isomerization of peroxynitrite to nitrate, Biochemistry 42 (2003) 14036-14046.

[43] S. Herold, S. Kalinga, T. Matsui, Y. Watanabe, Mechanistic studies of the isomerization of peroxynitrite to nitrate catalyzed by distal histidine metmyoglobin mutants, J. Am. Chem. Soc. 126 (2004) 6945-6955.

[44] M. Exner, S. Herold, Kinetic and mechanistic studies of the peroxynitritemediated oxidation of oxymyoglobin and oxyhemoglobin, Chem. Res. Toxicol 13 (2000) 287-293. 